\title{
A rare case of intrathoracic fetus in fetu / mature teratoma - pathological and imagistic aspects
}

\author{
Alin Dragoş Demetrian ${ }^{1)}$, Alexandra Floriana Nemeş's), Adrian Macovei ${ }^{3)}$, \\ CAMElia Demetrian ${ }^{4}$, Dana Maria AlbulesCu5), Cristian CONSTANTIN ${ }^{5)}$ \\ 1) Department of Thoracic Surgery, University of Medicine and Pharmacy of Craiova, Romania \\ 2) Department of Neonatology, Louis Turcanu Clinical Emergency Hospital for Children, Timişoara, Romania \\ 3) Department of Extreme Conditions Medicine, University of Medicine and Pharmacy of Craiova, Romania \\ 4) Department of Pulmonology, Victor Babeş Hospital of Infectious Diseases and Pneumophthisiology, Craiova, \\ Romania \\ 5) Department of Radiology and Medical Imaging, University of Medicine and Pharmacy of Craiova, Romania
}

\begin{abstract}
Fetus in fetu (FIF) is a rare entity, with a difficult preoperative diagnosis, frequently being an intraoperative surprise. In recent literature, theories pertaining to its development either assimilate the tumor with a monochorionic twin that halted its evolution, or with a highly differentiated mature teratoma. We present the case of a 27 -year-old patient, with a cystic tumor in the anterior mediastinum, which intraoperatively proved to be a rare case of intrathoracic FIF. The clinical presentation lacked any specific clues that would infer such a diagnosis; imaging was partially useful as it shown the possible existence of bone structures, heterogeneously mixed with fatty inclusions and other types of tissue. Upon surgery, the nature of said tumor was clear, and pathology confirmed the FIF diagnosis, showing different types of epithelia and tissue of several organ-like structures that halted in evolution at an early stage. Concluding our presentation, we can say that the presence of an axial skeleton as well as differentiated tissue types of several organs could confirm our case of FIF.
\end{abstract}

Keywords: fetus in fetu, mediastinum, tumor, pathological aspects, imaging.

\section{a Introduction}

Fetus in fetu (FIF) is a rare congenital anomaly with an incidence of one per 500000 births [1]. Taher et al. found 224 FIF reported cases [2]. There are two main theories regarding FIF development: the most prominent is that FIF is in fact a monochorionic twin, which is stopped in evolution and then incorporated into one's body [3]. According to Rahman et al., the mechanism could be either fissional or fusional, more evidence pointing toward fusional (diamniotic) mechanism [4]. A more fringe one is that a FIF in fact a highly differentiated "fetiform" mature teratoma, a nongerminomatous germ cell tumor (NGGCT) class [5].

Johann Friedrich Meckel introduced the FIF concept as early as $18^{\text {th }}$ century, were advanced genetic and histological test were largely unavailable, but little progress has been showing since, and as today a FIF case definition still includes morphological features, and as per Willis' definition, a well-developed vertebral axis is mandatory for case definition. Well-developed organs are not mandatory for case definition but are often encountered in reports. Because highly developed teratoma have also been reported, the Willis requirement of fetal-like appearance beyond notochord-neural tube-spine development is still, as today, the marker for FIF. The difference is important as mature teratomas are associated with higher malignant transformation risk, so the surgery should follow oncological principles [6].

The most common site for FIF is retroperitoneum, but they have in found in cranial cavity [7, 8], oral cavity [9], neck, thorax [10], liver [11], spleen, adrenal gland and sacrococcygeal regions [12]. Normally, most cases are reported in infants, but several cases have been reported in adults. The diagnostic is most commonly put by ultrasound (US), computed tomography (CT) and magnetic resonance imaging (MRI) being indicated for differential diagnostic and preoperatory setup. Certitude diagnostic is based solely on after operatory histological examination. Of course, the only treatment is surgical sanction [13].

There are genetic criteria for study FIF, but in a 1999 2013 metanalysis, the genetic testing was seldom use [14]. Regarding FIF in adults, Menon study found six male cases (20-47 years old) and two female cases (17-30 years old), all located retroperitoneal, with one exception [15], already mentioned. There are reports of thoracic FIF, but most in infants $[10,16,17]$. The only report like our case that was found was Massad et al. [18]. The FIF mediastinal location is rare, with only five cases described so far, only two of which were located in the anterior mediastinum [5].

\section{Aim}

We present a rare case of anterior mediastinal tumor that presented both characteristic features of FIF and mature teratoma aspects. These aspects of the mediastinal tumor were analyzed by CT and after surgical resection by macroscopically and microscopically morphopathological and histological study of the surgical specimen.

This is an open-access article distributed under the terms of a Creative Commons Attribution-NonCommercial-ShareAlike 4.0 International Public License, which permits unrestricted use, adaptation, distribution and reproduction in any medium, non-commercially, provided the new creations are licensed under identical terms as the original work and the original work is properly cited. 


\section{ㅁ Case presentation}

We present the case of a 27 -year-old man, currently smoking, with a very good clinical status, who was admitted in our Department of Thoracic Surgery for chest discomfort as the only and non-permanent symptom. The chest X-ray showed an oval opacity, well-defined, of sub-mediastinal intensity, with the most likely mediastinal affiliation (Figure 1).

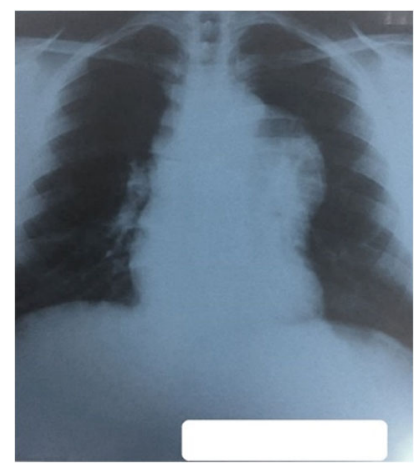

Figure 1 - Preoperative chest X-ray.

A CT scan examination with contrast substance was decided, which revealed the following aspects: welldefined $10 / 8 \mathrm{~cm}$ mediastinal mass, located in the anterior mediastinum, containing fat densities, soft parts, and bone-like structures; sagittal and coronal reconstructions demonstrated the existence of vertebrae and cox bones (Figure 2).

The radio-imaging investigations led us to the suspicion of a mature mediastinal teratoma, and after checking the biochemical exams (normal values), as well as the results of cardiology and cardiac US, we decided surgical resection.

Because of the relatively large size and location of the tumor, it has been decided to use the median completes sternotomy as the surgical approach. Intraoperatively, a cystic tumor of approximately $10 / 6 \mathrm{~cm}$ located in the left anterior part of the mediastinum, with thickened walls, relatively well delimited, excepting a tight adherence to the aortic arch.
Initially, a complete excision was attempted, but due to adherence to the aortic arch, it was necessary to previously puncture the tumor. After a small incision of the anterior wall, $50 \mathrm{~mL}$ of pus was evacuated, as well as hair tangles that were in contact with a solid tumor of tough, bony, irregular structure with dimensions of about $6 / 5 \mathrm{~cm}$ that did not have adhesions to the external cystic wall. This internal structure was mobile and floating in the liquid pus so that it could easily be extracted after widening the cystic wall incision. The solid inner tumor was macroscopically examined (and subsequently measured and photographed - Figure 3) having an unusual look very similar to a fetal skull: almost perfectly round shape, hair tresses, palpebral and auricular sketches and even a well-developed canine (Figure 4).

After the removal of this inner tumor, the remaining pus content was also evacuated. The quasi-complete excision of the cystic wall was practiced, with the abandonment of a minimum area of approximately $1 / 1 \mathrm{~cm}$ on the arch of the aorta.

The entire intervention was carried out without major blood losses and without the opening of the pleural spaces despite the large dimensions of the tumor. After thoroughly washing with hydrogen peroxide and drainage of the anterior mediastinum, the sternotomy was closed with three stainless steel wires.

The postoperative course was simple, uneventful, allowing rapid suppression of the mediastinal drain and patient discharge on the fourth postoperative day. Sternotomy was cured per primam, the radiological control was normal, the postoperative pain was minimal and rapid postoperative recovery was achieved.

The anatomopathological examination revealed respiratory and mucosal epithelial gland (Figure 5), adipose tissue with giant multinucleated cells (Figure 6), skin with sebaceous glands and hair (Figure 7), compact bone tissue and bone marrow (Figure 8).
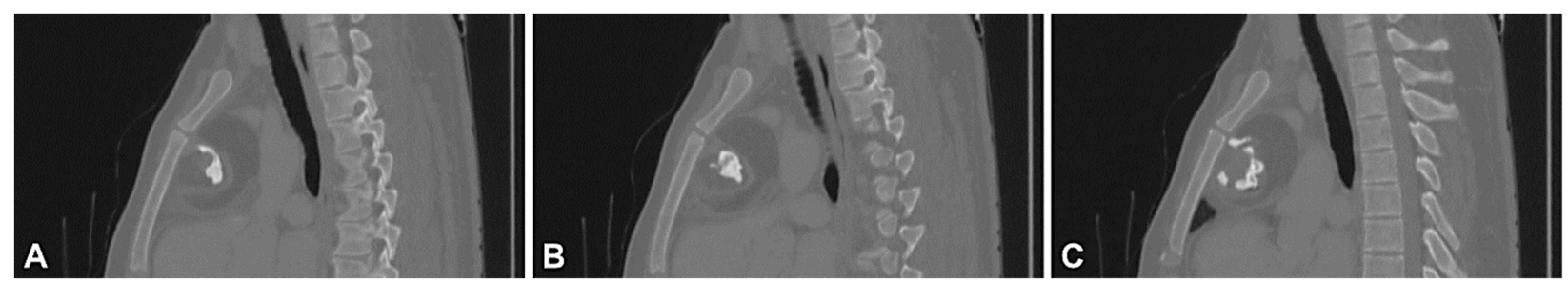

Figure $2-(A-C) C T$ reconstructions in the sagittal plane (bone window): the presence of the vertebral bodies, ribs, and the cox bones (CT 20 slice). CT: Computed tomography.

Figure $3-(A-C)$ CT reconstructions in the sagittal and coronal plane (parenchyma window, postcontrast): massive, well-defined mediastinal tumor, containing fat, soft hair, bone structures. CT: Computed tomography.
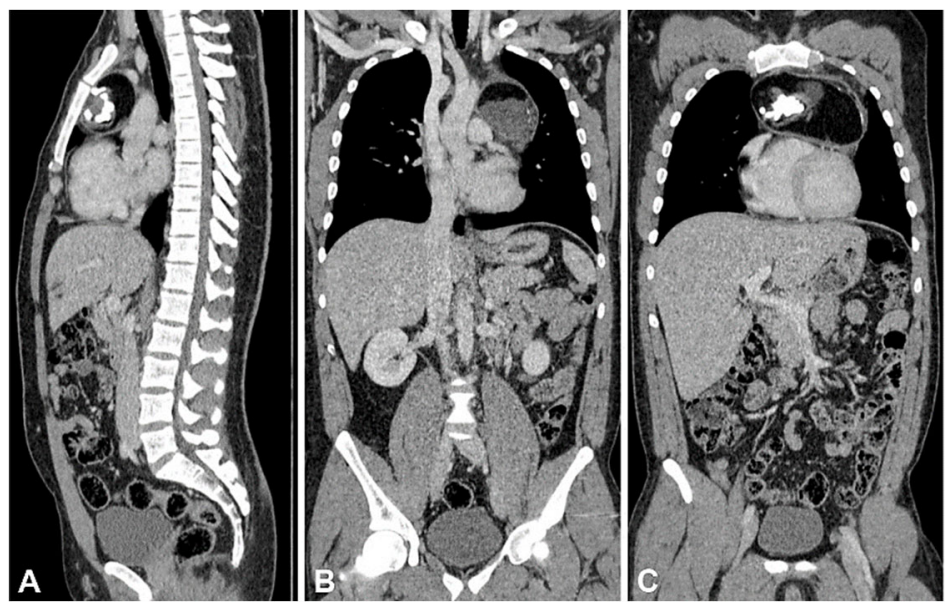
Figure $4-(A-C)$ Macroscopic details and size of the tumor, as observed immediately after surgical removal.

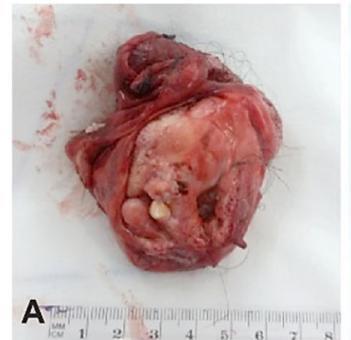

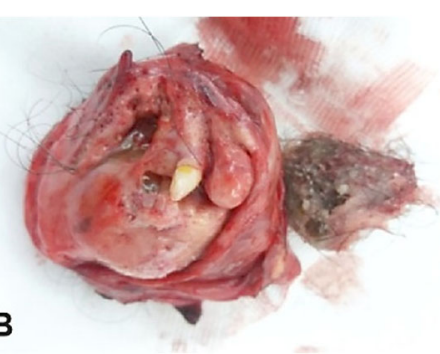

C

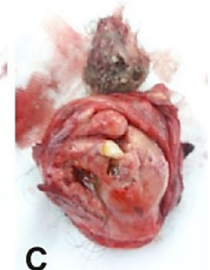

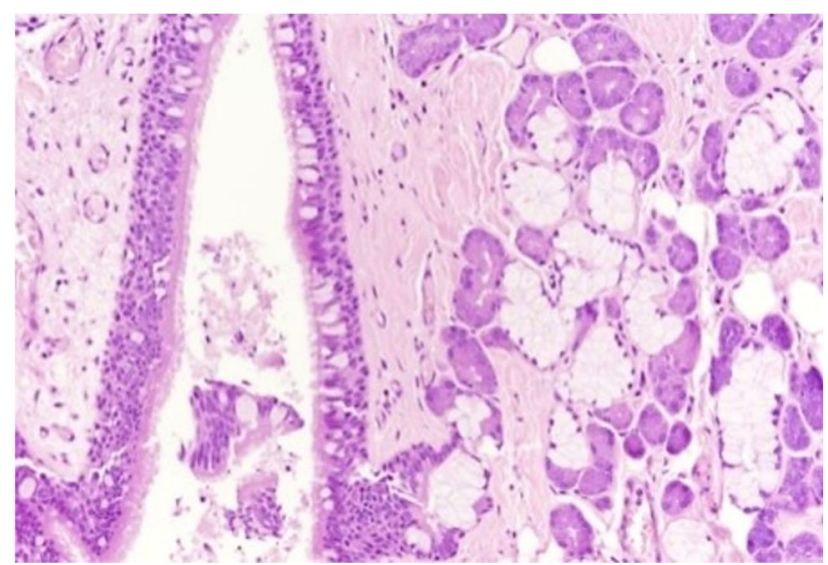

Figure 5 - Respiratory epithelium and mucoserous glands (HE staining, $\times 200)$. HE: Hematoxylin-Eosin.

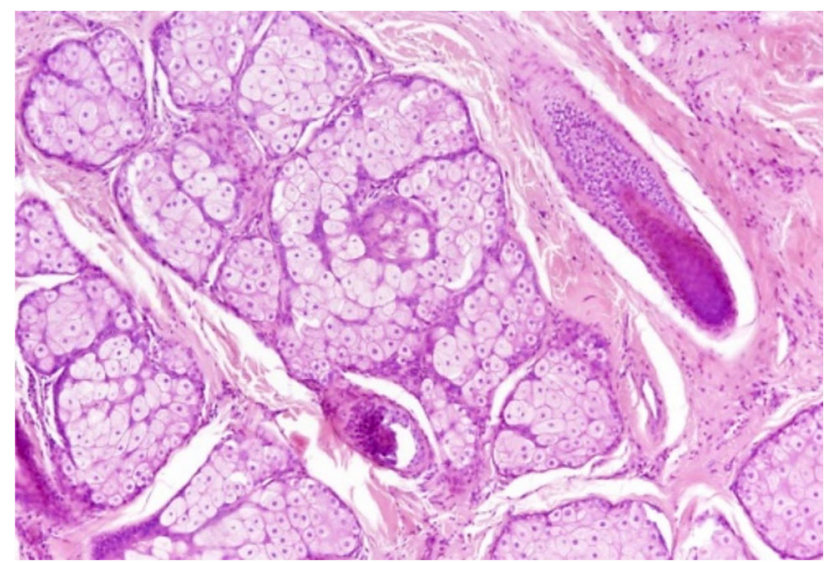

Figure 7 - Tegmentum with sebaceous glands and hair (HE staining, $\times 200)$.

\section{ㅁ Discussions}

The presence of a well-defined vertebral axis is crucial for Willis' definition, but in Prescher's metanalysis the presence of a well-developed vertebral column was identified in $76 \%$ of the included cases. Prescher concludes that FIF and mature teratoma are not a different pathology, but the same one stopped in different development stages [14]. The differentiation can clearly be made with other types of tumors, including metastases from other cancers [19], and postoperative recovery is usually satisfactory [20].

According to Willis' definition, cited by Prescher [14], the features that distinguish a FIF from a fetiform teratoma are: $(i)$ a separate spinal column, evidence of a neural tube development, followed by metamerization, (ii) symmetrical development, (iii) organs developed in a "synchronized" way, so they have a similar degree of maturation.

Prescher [14] review found that a quarter of cases had no spinal column, so many reports of a FIF lack this element.

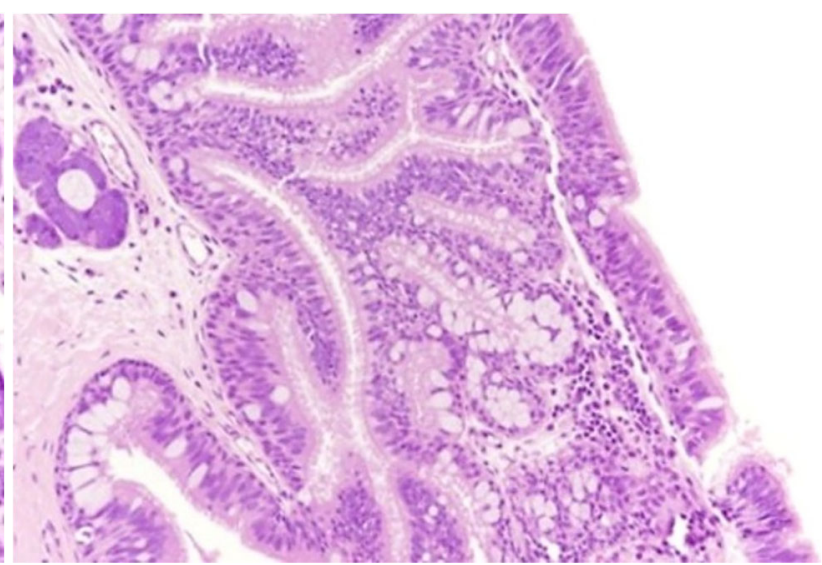

Figure 6 - Adipose tissue with inflammatory infiltration and giant multinucleated cells (HE staining, $\times 200)$.

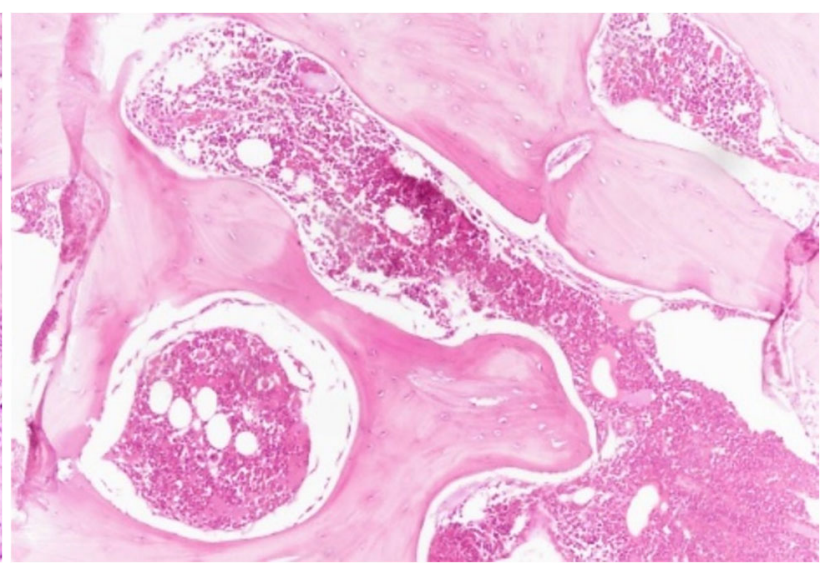

Figure 8 - Compact bone tissue and bone marrow (HE staining, $\times 100$ ).

The Gunaydin et al. report [17] found a well-developed spine in two of the three cases of thoracic FIF in infants. Mohta \& Khurana [21] suggested that at least $10 \%$ of FIF cases reported in the literature have no evidence of an axial skeleton. To complicate matters even further, there are reports of synchronous or sequential FIF-teratoma, with genetic grouping showing identical results in the affected infant and FIF/teratoma.

Gangopadhyay et al. [22] showed a clear identification of a vertebral column proving that fetal development of the included twin had advanced at least beyond the primitive streak stage (12 to 15 days of gestation) to a notochord, which is the precursor of the vertebral column.

Spencer [6] proved that due to statistically significant association of the FIF/teratomas in conjoined twins, all those anomalies formed a "development continuum". Common patterns found were the history of familiar twinning, female dominance, and frequent twin/triplet presentation. Wobenjo \& Osawa [23] case report states 
that FIF and teratomas can coexist, supporting Spencer theory of development continuum.

Spencer [6] proposed as the principal etiological factor the absence of heart development, subsequently followed by brain maldevelopment. Sharma also proposed a similar mechanism by following vascular distribution in FIF. He proposed the following as diagnostic criteria for FIF: (i) amniotic sac, (ii) normal skin, (iii) well-developed anatomical parts, (iv) attached by proper vasculature.

Pace et al. [24] defined in a case report the fetiform teratoma, a subset of mature teratoma. According to Pace et al., mature fetiform teratoma is even rarer than FIF, with about 25 cases being reported so far.

Although Pace et al. gives credit to classical FIF definition, admits that a differential diagnostic between fetiform teratoma and FIF is sometimes hard to make.

According to Sharma et al. [25], common organs for FIF include spine and limbs, with gastrointestinal and thymic tissues more often encountered. Thyroid, parathyroid, pancreas, spleen, kidney, adrenal, testis, ovaries, urinary bladder, tongue, salivary glands, lymph nodes, trachea, and teeth tissues were also reported. Surana et al. [8] showed that most FIF report have spinal column (over 90\%) and limbs (over 80\%), and all were anencephalic. Most site was retroperitoneal with abdomen, scrotum, cranium, kidneys, adrenals, mediastinum, and lymph nodes being cited.

Taher et al. [2] report, although acknowledging the possibility of lacking a well-developed spinal column, states that all of their cases were FIF due to the present of skin, well-formed organs and a vestigial amniotic sac. He also admits a probable reporting bias towards FIF, due to the spectacular component.

Faizi et al. [26], in a case report, support Heifetz et al. [27] theory of a pathological identity between FIF and teratoma.

Highly differentiated teratomas [28] have a low chance of malignant evolution, 6-10\% according to Escobar et al. [29]. FIF was believed to be malignant-free, but a report from Hopkins et al. [30] proved otherwise.

Mills et al. [31] concluded that FIF is in fact "the highest possible organized form" of a mature teratoma, calling current criteria arbitrary and not definite marks of different pathological evolution/stage, citing the need of more genetic testing.

Boyce et al. [32] automated screening model is believed to be able to make a difference between FIF and teratomas based on their zygotism.

Harms et al. [33] make a good case towards histological differentiation, stating that the main characteristic of a teratoma is the "histological potpourri", an amalgam of possible well-developed tissues, lacking any organization.

Miura et al. [34] brings strong evidence towards monozygoticism of FIF and supports the monozygotic dichorionic diamniotic developmental theory of FIF.

According to Ji et al. [12, 35], FIF should arise from a zygote at primitive streak stage, the mass developing by following normal fetal development rules until it is stopped in evolution. A teratoma would originate from multiple pluripotent cells, without organogenesis or vertebral segmentation. While this approach highlights very well the extremes, give little help of managing more complex cases. In the end, they admit that there is a great amount of overlapping between FIF and teratoma and genetic testing should be more prevalent, proposing karyotyping, serological marker assessment, and deoxyribonucleic acid (DNA) restriction site mapping as useful investigations. Most teratomas should be heterozygotes, and most FIF should be monozygotic.

On the other hand, Peterson et al. [36] review found that teratomas account for $75 \%$ of mediastinal germ cell tumors, and usually pertains to anterior mediastinum, near thymus. Most are of mature type. Malignant development is almost exclusive to men. Cystic structure with fat inclusion and calcification should be the rule. According to Carter et al. [37], 10\% of the common anterior mediastinal masses are benign teratomas.

Similar to our case, the Kumar et al. [38] case report showed that although their case did not follow exactly Willis or Spencer rules, the evidence of skin and bone formation would be strong enough support for FIF, also calling for a revised definition based on Spencer modified criteria.

Weiss et al. [39] classified as teratoma a case with rudimentary spine, although many similar cases were reported as FIF. They also add that skeletal musculature was never found in a teratoma.

Cingel et al. [5] described the fourth reported case of FIF located in the thorax, and the second case located in the anterior mediastinum.

Recent reports of FIF cases in adults were scarce [25, 38].

In our case, the mediastinal mass presented two vertebrae, ribs and cox bones anteriorly articulated, so we can state the presence of the axial skeleton as the basic feature of the FIF. But we have not found individual organs or limbs. Our histopathological analysis revealed the presence of tegument, fat, bone tissue, respiratory epithelium.

Depending on the tumor-adjacent anatomical structures, clinical manifestations may vary from a simple chest discomfort to respiratory or cardiac disorders due to the compressive effect of the tumor on the airway, heart, or large vessels [40, 41].

There are also described cases of broken teratomas in respiratory tract or lung tissue, followed by infectious syndrome [42].

The small-size teratomas with no mass effect on adjacent mediastinal structures may remain undiagnosed, and their discovery may be incidental when conducting radio-imaging investigations for another pathology.

The pluripotency of teratomas (i.e., the ability to form several types of cells), derives from the fact that they can give birth to very varied anatomical structures including hair, tooth, pituitary gland, and even fully formed eyeball $[28,43]$.

So remains this question: mature teratoma or FIF?

In our case, we have the following aspects: vertebrae are present; there is a tissue differentiation close to the organ differentiation of the three embryonic layers: ectoderm (sebaceous glands, hair), mesoderm (bones, adipose tissue) and endoderm (respiratory epithelium). Also, the mediastinal location, although very rare, is more common in fetus than in teratoma (present in gonads - most often ovaries-dermoid 
cysts or pelvis). But the epithelium surrounding the formation is pavementous, characteristic of the teratoma and not cubic, as mentioned in the FIF cases.

We will follow the case for at least two years and then will report the presence/absence of recurrences or malignant transformation.

\section{ㅁ Conclusions}

The presence of anatomical structures of the axial skeleton, but the absence of well differentiated organs in our case, demonstrates that the two entities, the FIF and the mature teratoma, cannot be distinguished clearly.

\section{Conflict of interests}

The authors declare that they have no conflict of interests.

\section{Authors' contribution}

Alin Dragoş Demetrian and Alexandra Floriana Nemeş equally contributed to this article and share main authorship.

\section{References}

[1] Matsubara N, Akasaka Y, Kanagaki M, Okamoto S. A case report of fetus in fetu with an aorta-like structure visualized by contrast-enhanced CT. Radiol Case Rep, 2020, 15(12):26452648. https://doi.org/10.1016/j.radcr.2020.10.006 PMID: 33088380 PMCID: PMC7567927

[2] Taher HMA, Abdellatif M, Wishahy AMK, Waheeb S, Saadeldin Y, Kaddah S, Abdulsattar AH, Osman MA, El Tagy GH, Elbarbary MM, Khairi A, Tawfik S, Anis S, Anis E, Farouk M, Abdelfattah $\mathrm{AH}$, Muensterer OJ. Fetus in fetu: lessons learned from a large multicenter cohort study. Eur J Pediatr Surg, 2020, 30(4):343-349. https://doi.org/10.1055/s-0039-1698765 PMID: 31770783

[3] Basu A, Jagdish S, lyengar KR, Basu D. Fetus in fetu or differentiated teratomas? Indian J Pathol Microbiol, 2006, 49(4):563-565. PMID: 17183856

[4] Rahman MM, Chakravarty S, Barua T. Fetus in fetu: case report of a Bangladeshi girl. Hum Pathol Case Rep, 2020, 22:200450. https://doi.org/10.1016/j.ehpc.2020.200450 https://www.science direct.com/science/article/pii/S2214330020300997?via\%3Dihub

[5] Cingel V, Durdik S, Babala J, Polak S, Varga I. Fetus in fetu from newborn's mediastinum: case report and a review of literature. Surg Radiol Anat, 2012, 34(3):197-202. https:// doi.org/10.1007/s00276-011-0868-9 PMID: 21901374

[6] Spencer R. Parasitic conjoined twins: external, internal (fetuses in fetu and teratomas), and detached (acardiacs). Clin Anat 2001, 14(6):428-444. https://doi.org/10.1002/ca.1079 PMID: 11754238

[7] Yang ST, Leow SW. Intracranial fetus-in-fetu: CT diagnosis. AJNR Am J Neuroradiol, 1992, 13(5):1326-1329. PMID: 1414822 PMCID: PMC8335217

[8] Surana A, Aggarwal A, Krishnan V, Malik A, Misra RN. Intracranial fetus in fetu - a pediatric rarity. World Neurosurg, 2020, 139:286-288. https://doi.org/10.1016/j.wneu.2020.03.156 PMID: 32247796

[9] Aslanabadi S, Spinner RJ, Zarrintan S, Ghasemi B, JabbariMoghaddam Y, Khaki AA, Sadat AT. A neonate with cleft palate and a fetal mass in the oral cavity: a rare case of an oral fetus-in-fetu. Int J Pediatr Otorhinolaryngol, 2007, 71(10):16171622. https://doi.org/10.1016/j.jporl.2007.05.033 PMID: 17628706

[10] Reddy RK, Kannaiyan L, Srirampur S, Malleboyina R, Irfan GM, Sharab H, Kannepalli S. Thoracic fetus in fetu. J Indian Assoc Pediatr Surg, 2012, 17(4):178-179. https://doi.org/10.4103/ 0971-9261.102344 PMID: 23243374 PMCID: PMC3519000

[11] Magnus KG, Millar AJ, Sinclair-Smith CC, Rode H. Intrahepatic fetus-in-fetu: a case report and review of the literature. J Pediatr Surg, 1999, 34(12):1861-1864. https://doi.org/10.1016/s002 2-3468(99)90333-0 PMID: 10626875

[12] Ji Y, Song B, Chen S, Jiang X, Yang G, Gao X, Xiang B. Fetus in fetu in the scrotal sac: case report and literature review. Medicine (Baltimore), 2015, 94(32):e1322. https://doi.org/
10.1097/MD.0000000000001322 PMID: 26266375 PMCID: PMC4616709

[13] Ruffo G, Di Meglio L, Di Meglio L, Sica C, Resta A, Cicatiello R. Fetus-in-fetu: two case reports. J Matern Fetal Neonatal Med, 2019, 32(17):2812-2819. https://doi.org/10.1080/14767058. 2018.1449207 PMID: 29804477

[14] Kumar A, Paswan SS, Kumar B, Kumar P. Fetus in fetu in an adult woman. BMJ Case Rep, 2019, 12(8):e230835. https:// doi.org/10.1136/bcr-2019-230835 PMID: 31409619 PMCID: PMC6700597

[15] Xiaowen M, Lingxi C, Song L, Shengbao P, Xiaohong $Y$, Xinghai $Y$. Rare fetus-in-fetu: experience from a large tertiary pediatric referral center. Front Pediatr, 2021, 9:678479. https:// doi.org/10.3389/fped.2021.678479 PMID: 34109141 PMCID: PMC8180561

[16] Janovski NA. Fetus in fetu. J Pediatr, 1962, 61:100-104. https:// doi.org/10.1016/s0022-3476(62)80236-4 PMID: 14451195

[17] Gunaydin M, Celik FC, Tander B, Bozkurter AT, Sullu Y, Baris S, Rizalar R, Kucukoduk S. Two cases of fetus in fetu. J Pediatr Surg, 2011, 46(9):e9-e12. https://doi.org/10.1016/j. jpedsurg.2011.05.012 PMID: 21929974

[18] Massad MG, Kong L, Benedetti E, Resnick D, Ghosh L, Geha AS, Abcarian $\mathrm{H}$. Dysphagia caused by a fetus-in-fetu in a 27 -year-old man. Ann Thorac Surg, 2001, 71(4):1338-1341. https://doi.org/ 10.1016/s0003-4975(00)02291-8 PMID: 11308184

[19] Albulescu DM, lonovici N, Moldovan HR, Demetrian AD, Bălă VS, Constantin C, Bumbea AM, Pănuş C, Albu VC. Muscle metastases from cervical carcinoma - case report. Rom J Morphol Embryol, 2017, 58(2):545-551. PMID: 28730241

[20] Olaru M, Mălăescu D, Demetrian A, Ioncică L, Stănoiu B, Drâgnei $D$. A combined imagistic and morphological approach of lung tumors: study on 64 cases. Rom J Morphol Embryol, 2013, 54(4):1067-1074. PMID: 24399003

[21] Mohta A, Khurana N. Fetus-in-fetu or well-differentiated teratoma - a continued controversy. Indian J Surg, 2011, 73(5):372-374. https://doi.org/10.1007/s12262-011-0251-4 PMID: 23024547 PMCID: PMC3208714

[22] Gangopadhyay AN, Srivastava A, Srivastava P, Gupta DK, Sharma SP, Kumar V. Twin fetus in fetu in a child: a case report and review of the literature. J Med Case Rep, 2010, 4:96. https://doi.org/10.1186/1752-1947-4-96 PMID: 20338036 PMCID: PMC2852393

[23] Wobenjo A, Osawa F. Fetus in fetu: a case report and review of literature. Ann Afr Surg, 2010, 6:56-59. https://doi.org/10. 4314/aas.v6i1.63248 https://www.ajol.info//index.php/aas/article/ view/63248

[24] Pace S, Sacks MA, Goodman LF, Tagge EP, Radulescu A. Antenatal diagnosis of retroperitoneal cystic mass: fetiform teratoma or fetus in fetu? A case report. Am J Case Rep, 2021, 2:e929247. https://doi.org/10.12659/AJCR.929247 PMID: 33568621 PMCID: PMC7885532

[25] Sharma S, Gupta PK, Regmi B, Gupta A, Lamichhane U. Fetus in fetu in an adult female and brief review of literature. Case Rep Radiol, 2021, 2021:6660277. https://doi.org/10. 1155/2021/6660277 PMID: 33628563 PMCID: PMC7895588

[26] Faizi FR, Rasouly N, Aien MT. Fetus in fetu or fetiform teratoma? Report of two cases. J Pediatr Surg Case Rep, 2020, 61:101605. https://doi.org/10.1016/j.epsc.2020.101605 https://www.science direct.com/science/article/pii/S2213576620302396?via\%3Dihub

[27] Heifetz SA, Alrabeeah A, Brown BS, Lau H. Fetus in fetu: a fetiform teratoma. Pediatr Pathol, 1988, 8(2):215-226. https:// doi.org/10.3109/15513818809022299 PMID: 3045784

[28] Gonzalez-Crussi F, Winkler RF, Mirkin DL. Sacrococcygeal teratomas in infants and children: relationship of histology and prognosis in 40 cases. Arch Pathol Lab Med, 1978, 102(8):420-425. PMID: 580884

[29] Escobar MA, Rossman JE, Caty MG. Fetus-in-fetu: report of a case and a review of the literature. J Pediatr Surg, 2008, 43(5):943-946. https://doi.org/10.1016/j.jpedsurg.2008.01.061 PMID: 18485974

[30] Hopkins KL, Dickson PK, Ball TI, Ricketts RR, O'Shea PA, Abramowsky CR. Fetus-in-fetu with malignant recurrence. J Pediatr Surg, 1997, 32(10):1476-1479. https://doi.org/10. 1016/s0022-3468(97)90567-4 PMID: 9349774

[31] Mills P, Bornick PW, Morales WJ, Allen M, Gilbert-Barness E, Johnson PK, Quintero R. Ultrasound prenatal diagnosis of fetus in fetu. Ultrasound Obstet Gynecol, 2001, 18(1):69-71. https:// doi.org/10.1046/j.1469-0705.2001.00469.x PMID: 11489230 
[32] Boyce MJ, Lockyer JW, Wood CB. Foetus in foetu: serological assessment of monozygotic origin by automated analysis. J Clin Pathol, 1972, 25(9):793-798. https://doi.org/10.1136/ jcp.25.9.793 PMID: 4673613 PMCID: PMC477513

[33] Harms D, Zahn S, Göbel U, Schneider DT. Pathology and molecular biology of teratomas in childhood and adolescence. Klin Padiatr, 2006, 218(6):296-302. https://doi.org/10.1055/ S-2006-942271 PMID: 17080330

[34] Miura S, Miura K, Yamamoto T, Yamanaka M, Saito K, Hirabuki T, Kurosawa K, Harada N, Ishizaki-Yamasaki Y, Matsumoto N, Hirahara F, Yoshiura K, Masuzaki H, Niikawa N. Origin and mechanisms of formation of fetus-in-fetu: two cases with genotype and methylation analyses. Am J Med Genet A 2006, 140(16):1737-1743. https://doi.org/10.1002/ajmg.a.31362 PMID: 16835914

[35] Ji Y, Chen S, Zhong L, Jiang X, Jin S, Kong F, Wang Q, Li C Xiang B. Fetus in fetu: two case reports and literature review. BMC Pediatr, 2014, 14:88. https://doi.org/10.1186/1471-243 1-14-88 PMID: 24693883 PMCID: PMC3996905

[36] Peterson CM, Buckley C, Holley S, Menias CO. Teratomas: a multimodality review. Curr Probl Diagn Radiol, 2012, 41(6): 210-219. https://doi.org/10.1067/j.cpradiol.2012.02.001 PMID: 23009771

[37] Carter BW, Marom EM, Detterbeck FC. Approaching the patient with an anterior mediastinal mass: a guide for clinicians. J Thorac Oncol, 2014, 9(9 Suppl 2):S102-S109. https://doi.org/10.1097/ JTO.0000000000000294 PMID: 25396306
[38] Kumar AN, Chandak GR, Rajasekhar A, Reddy NC, Singh L. Fetus-in-fetu: a case report with molecular analysis. J Pediatr Surg, 1999, 34(4):641-644. https://doi.org/10.1016/s0022-3 468(99)90095-7 PMID: 10235344

[39] Weiss JR, Burgess JR, Kaplan KJ. Fetiform teratoma (homunculus). Arch Pathol Lab Med, 2006, 130(10):1552-1556. https://doi.org/10.5858/2006-130-1552-FTH PMID: 17090201

[40] Asteriou C, Barbetakis N, Kleontas A, Konstantinou D. Giant mediastinal teratoma presenting with paroxysmal atrial fibrillation. Interact Cardiovasc Thorac Surg, 2011, 12(2):308-310. https:// doi.org/10.1510/icvts.2010.253039 PMID: 21075832

[41] Man MA, Arghir OC, Man S, Streba CT, Olteanu M, Niţu M. Fatal paradoxical cryptic miliary tuberculosis and immune reconstitution disease in a young non-HIV immunocompromised male patient: case report with autopsy findings. Rom J Morphol Embryol, 2014, 55(2):453-457. PMID: 24970001

[42] Serraj M, Lakranbi M, Ghalimi J, Ouadnouni Y, Smahi M. Mediastinal mature teratoma with complex rupture into the lung, bronchus and skin: a case report. World J Surg Oncol, 2013, 11:125. https://doi.org/10.1186/1477-7819-11-125 PMID: 23725382 PMCID: PMC3674925

[43] de Lagausie P, de Napoli Cocci S, Stempfle N, Truong QD, Vuillard E, Ferkadji L, Aigrain Y. Highly differentiated teratoma and fetus-in-fetu: a single pathology? J Pediatr Surg, 1997, 32(1):115-116. https://doi.org/10.1016/s0022-3468(97)90112-3 PMID: 9021587

\section{Corresponding authors}

Dana Maria Albulescu, MD, PhD, Department of Radiology and Medical Imaging, University of Medicine and Pharmacy of Craiova, 2 Petru Rareş Street, 200349 Craiova, Dolj County, Romania; Phone +40742-745 748, e-mail: med73danam@yahoo.com

Adrian Macovei, Teaching Assistant, MD, PhD, Department of Extreme Conditions Medicine, University of Medicine and Pharmacy of Craiova, 2 Petru Rareş Street, 200349 Craiova, Dolj County, Romania; Phone +40351-443 561, e-mail: adrian.macovei@gmail.com 